\title{
Mole per Liter per Microgram
}

National Cancer Institute

\section{Source}

National Cancer Institute. Mole per Liter per Microgram. NCI Thesaurus. Code C119443.

A unit of concentration equal to moles per liter, divided by micrograms. 